\title{
Chapter 3 \\ Natural Capital, Material Flows, \\ the Landscape and the Economy
}

\author{
Harry Lintsen
}

\section{Contents}



3.2 Natural Capital: Water, Air and Soil........................................................................ 50

3.3 Agriculture and Nutrition: Organic Raw Materials............................................................. 52

3.3.1 Mixed Farming on the Sand Grounds....................................................................... 52

3.3.2 Grassland Farming in the Low-Lying Peat Marshes................................................. 54

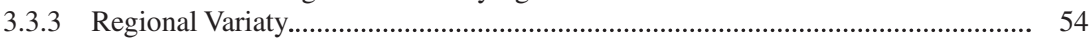

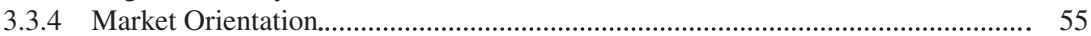

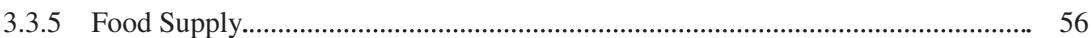

3.4 Building Materials and Construction: Mineral Resources................................................... 57

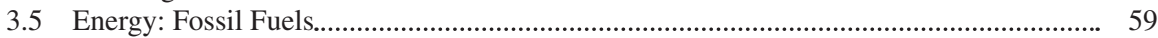

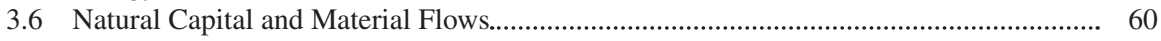

3.7 A Variegated Landscape

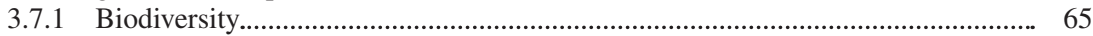

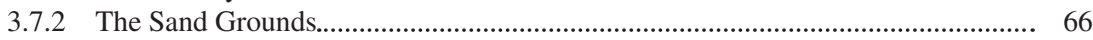



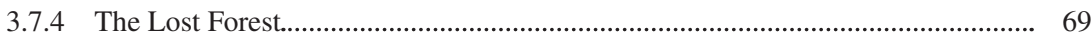

3.7.5 Prosperous Farming Landscape ............................................................................ $\quad 70$

3.8 A growing Economy, a Growing Population............................................................... 72

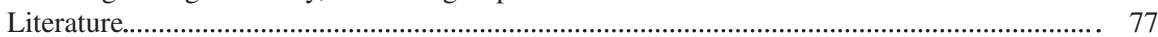

\begin{abstract}
In this study, natural capital occupies a special place. After all, the way natural capital is exploited is crucial for issues of well-being and sustainability. This chapter analyses the exploitation of natural capital in the Netherlands around 1850. It deals with three categories of resources produced by natural capital.

First, organic resources (including grains, potatoes, cattle and milk) and the associated supply chains in agriculture and foods (farming systems, food production and food consumption).

Second, mineral subsoil resources (in particular sand, clay and gravel) and the associated supply chains in construction (housing construction, water management, and infrastructure).
\end{abstract}

This chapter is written by Harry Lintsen with contributions by Fred Lambert, Rick Hölsgens and Ben Gales.

H. Lintsen et al., Well-being, Sustainability and Social Development, 
Finally, fossil subsoil resources (in particular turf and coal) and the associated energy supply chains (industry and households).

The exploitation of natural capital took place in a variegated landscape possessing great biodiversity and an agricultural economy that provided plenty of room for population growth.

Keywords Natural capital · Agriculture · Foods · Construction · Energy · Biodiversity $\cdot$ Economy

\subsection{Recalcitrant Sand Grounds}

It was always hard work on the Dutch sand grounds. 'The rooster is the alarm clock of the farming family', as an official report on farm life puts it:

Work begins... in the early morning; crop farmers start in the summer at 4 and work until 8 o'clock in the evening, in the winter from 4 in the morning to 6 or 7 o'clock in the evening; grass or dairy farmers begin work an hour later in the winter and are done an hour earlier. ${ }^{1}$

Making manure was the core of farm work on the sand grounds. ${ }^{2}$ This demanded heavy labour and was therefore men's work: cutting peat sods on the heath, loading the wagon, mixing the peat with manure from the stable, mucking out the stable, transporting manure to the fields and spreading it out over the fields. Adequate fertilizing of the soil was the key to survival on the sand grounds. Tilling the soil as well as harvesting was also men's work: ploughing, harrowing, delving, mowing, threshing the grain, etc. That was also the case for a variety of tasks like cutting wood, preparing flax and everything to do with the horse or the ox. Evenings were devoted to making brooms, repairing halters for the horses, knotting ropes for the cows, sharpening knives and so on.

Women's work consisted of taking care of the cow, the calf, the pig and the chickens. The farmer's wife was responsible for milking and processing the milk, in particular churning it into butter. She also helped with harvesting, maintained the vegetable patch and provided meals for her husband and the children. Making and repairing clothes was reserved for the evenings. In North-Brabant much of her time

\footnotetext{
${ }^{1}$ J. Zeehuisen, 'Statistieke bijdrage tot de kennis van den stoffelijken en zedelijken toestand van de landbouwende klasse in het kwartier Salland, provincie Overijssel', in: J.L. Van Zanden, 'Den zedelijke en materiële toestand der arbeidende bevolking ten platten lande'. Een reeks rapporten uit 1851 (Historia Agriculturae XXI, Groningen 1991). Original source: Tijdschrift voor Staathuishoudkunde en Statistiek 6(1851), 380.

${ }^{2}$ For a description of farming on the sand grounds see A.H. Crijns en F.W.J. Kriellaars, Gemengd landbouwbedrijf op de zandgronden in Noord-Brabant 1800-1885, (Tilburg 1987); J. Bieleman, Boeren op het Drentse zand 1600-1910. Een nieuwe visie op de 'oude' landbouw (Wageningen 1987); J. Bieleman, Boeren in Nederland. Geschiedenis van de landbouw 1500-2000 (Amsterdam 2008 ) en G. van den Brink, De grote overgang. Een lokaal onderzoek naar de modernisering van het bestaan. Woensel 1670-1920 (Nijmegen 1996).
} 
was taken up with preparing slops for the cattle: three times a day in the winter and twice in the summer. ${ }^{3}$ For the slops, the farmer's wife used cut tuber greens and tubers, corn spurrey (greens, hay, chaff and husks), potatoes, carrots, rape siliqua, flax husks, clover, cut hay, chopped straw, sometimes buttermilk and when the mixture was cooked also 'cake water' (made from rape cakes soaked in water), while oat or rye flour was often also added to the brew. 'Without fodder no good cattle, no good manure, no good harvest, no profit...' thus was its importance described.

This important part of the enterprise rests largely on the woman, who from early morning to late evening toils for her cows and thus devotes little attention to her own home, because the time is needed in or for the stable: that is where she lives, there is her sole pride. ${ }^{4}$

Work was apportioned by sex but also by age. It was normal for children to be burdened with supporting tasks. From an early age they contributed by gathering wood, picking berries, digging up thistles and in some cases herding cattle in the fields. At the age of ten boys joined their fathers in helping to prepare the manure and work the land, while the girls helped the mother with her work.

On the bigger farms (on the sand grounds farms of more than 5 hectares) both the farmer and his wife had their hands full running their farm. ${ }^{5}$ Usually they had the help of one or more domestic farmhands and maids. That depended on the size of the farm and the number of eligible children. But the sand grounds were dominated by smallholders with farms of less than 5 hectares. Many owned only a small plot of land of a hectare or less on which they cultivated potatoes and some vegetables and kept a cow, pig, goat or a few chickens. This was often inadequate to make a living. So next to running their own little enterprise they worked on other farms or derived income from other activities. Threads were spun to order, textiles woven, mats braided etc. The whole family took part. A reporter from the province of Drenthe described the smallholder as follows:

He has very few needs and mostly a bit of land near his habitation and a Frisian sheep in the stable, sometimes a cow from Drenthe. He tills his soil in his free time, assisted by his wife and children; the sheep's wool serves for clothing; the vest jacket and the five-shaft coat are usually woven in the village itself; he is used to heavy labour... ${ }^{6}$

The sand grounds belong to the natural capital of the Netherlands. Natural capital occupies a special position in this study. It is viewed as the basis for quality of life (see Chap. 1). It is clear that natural capital does not bestow its favours without a struggle. It has enormous potential in the Netherlands, but its exploitation demands

\footnotetext{
${ }^{3}$ Bieleman, Boeren in Nederland, 266.

${ }^{4}$ Cited from: Van den Brink, De grote overgang, 125. Original source: W. van Iterson, Schets van de landhuishoudkunde der Meijerij (Groningen 1868), 85.

${ }^{5}$ Crijns en Kriellaars, Gemengd landbouwbedrijf op de zandgronden in Noord-Brabant, 78 en 85.

${ }^{6}$ P.W. Alstorphius Grevelink, 'Zedelijke en materiële toestand der arbeidende bevoking ten platten lande. Nopens Drenthe (1850)', in: J.L. Van Zanden, 'Den zedelijke en materiële toestand der arbeidende bevolking ten platten lande'. Een reeks rapporten uit 1851 (Historia Agriculturae XXI, Groningen 1991). Original source: Verslag van het verhandelde op het vijfde Nederlandsche Landhuishoudkundig Congres, gehouden te Leiden van den 10den tot den 14den junij 1850 (Leiden 1850), Appendix no 13, 111.
} 
tremendous efforts. This chapter develops the theme of natural capital. How can we characterize Dutch natural capital in the middle of the nineteenth century? What products did it help to produce and what services were provided? What were the consequences for nature? How did it contribute to economic growth? The next chapter examines the quality of life that was achieved in the Netherlands on the basis of that natural capital.

We begin with a characterization of natural capital and we do that in terms of colonised ecosystems. These are natural ecosystems that have been influenced by humans with the aim of producing products and services (see Chap. 1). We can characterize colonised ecosystems in the Netherlands in various ways, depending on the system boundaries we choose. Here we take water, air and soil as a point of departure. How was nature colonised around 1850? And to what degree were those systems sustainable?

\subsection{Natural Capital: Water, Air and Soil}

The Netherlands could (and can) be perceived as a large colonised water system, although with the reservation that in the nineteenth century the influence of the Dutch on that system was still limited. 110 billion cubic meters of fresh water annually flowed into the country, in part via the rivers and partly as precipitation. ${ }^{7}$ Most of this (about 80\%) left the country directly as it flowed into the sea. The rest evaporated (about 20\%). Less than $1 \%$ was used in agriculture, by households and in industry. Even that miniscule percentage still represented a useful material flow of millions of tons of water. The Dutch population would have consumed something like 2.0 to 2.6 million tons of water annually (directly as well as indirectly as a constituent of food). ${ }^{8}$

Water played a key role in the Netherlands in a number of ways. As in other countries it was an elixir of life for the population in the form of drinking water. In the nineteenth century there was much ado about its quality. We will return to this point. Moreover it was an essential factor of production in agriculture (including fisheries) and industry. In addition water in the Netherlands uniquely fulfilled two other roles, namely as a medium for transportation and trade and for territorial defence. ${ }^{9}$

\footnotetext{
${ }^{7}$ De Bosatlas van Nederland waterland (Groningen 2010), 57. Figures refer to the present-day situation and will be of the same order of magnitude as in 1850 . Only the percentage of water use in agriculture, households and industry has been adjusted from $4.5 \%$ at present to less than $1 \%$ at the earlier epoch. This seems realistic in view of the significantly smaller population and scope of economic activity.

${ }^{8}$ Adults need at least 2 to 2.5 liters of water per day (including water in foods); children older than one year 1.5 to 2 liters per day. We assumed an average of 1.8 to 2.3 liters. For a population of 3.1 million persons in the Netherlands around 1850 this amounts to 2.0 to 2.6 million tons of water (including water in foods).

${ }^{9}$ See: C. Disco and H.W. Lintsen, 'Het nijvere verbond', in: J. Schot, H.W.Lintsen, A. Rip and A.A. Albert de la Bruhèze (eds.), Techniek in Nederland in de twintigste eeuw (Zutphen 1998-
} 
Since medieval times, inner waters, lakes and large natural waterways played an essential role in regional, interregional and even international trade. In the course of the seventeenth century a dense network of tow-canals came into existence on which tow-barges operating on accurate schedules maintained regular connections among important cities and smaller towns. In the first half of the nineteenth century a number of new canals like the Zuid-Willemsvaart and the North-Holland Canal (Noord-Hollandsch Kanaal) were added. From this perspective, water was the necessary condition for the riches gathered by, in particular, the province of Holland. Water was the most important means of transport for commodities. It was from water that the Netherlands, that is, the Republic of the Seven United Provinces, derived its power as a trading nation.

Water was also the ally that helped defend the commercial position and the accumulated riches against foreign aggression. Various defensive water-lines were constructed in order to defend the economic and political heart of the Netherlands - namely the province of Holland and in particular Amsterdam. ${ }^{10}$ Water-lines operated on a simple principle: one opened the inundation sluices, ${ }^{11}$ flooding the polders and creating a treacherous undeep water surface with numerous invisible ditches. The enemy could advance only along the more elevated dikes and roads, but this was blocked by a system of strategically positioned forts and sconces.

It is nonetheless important to realize that the colonisation of nature regularly misfired and that nature could easily become counterproductive: the sea threatened the land with storm surges, the rivers regularly flooded broad swaths of countryside as they overtopped their levies, lakes, their surfaces whipped by heavy winds, could also cause flooding. The low-lying portion of the Netherlands struggled with a surfeit of water while the higher portion ran the risk of water shortages. Water was not only an ally but a water-wolf that had to be tamed.

In the first half of the nineteenth century colonised ecosystems were Janus-faced. That certainly applied to air as a source of life for humans, plants and animals. As a factor of production it played a crucial role in industrial heating and chemical processes. It was used in households to heat and cook. If we focus on the atmospheric and meteorological aspects of air, then we soon encounter weather and the extensive use of wind as a source of energy. Wind supplied the energy for thousands of windmills and sailing ships.

But air also had a problematic side. Cold and poor air quality caused flu, tuberculosis and other epidemic diseases. On calm days the windmills languished, in stormy weather ships perished, during extreme weather entire harvests were lost and human existence was hard.

2003), part I, 55-63; G.P. van de Ven (ed.), Leefbaar laagland. Geschiedenis van de waterbeheersing en landaanwinning in Nederland (Utrecht 1993); A. Bosch and W. van der Ham, edited by H.W. Lintsen, Twee Eeuwen Rijkswaterstaat 1798-1998 (Zaltbommel 1998).

${ }^{10}$ De oude Hollandse Waterlinie (1673), de Grebbelinie (1742), de nieuwe Hollandse Waterlinie (1815), de Stelling van Amsterdam (1880) en de IJssellinie (1951).

${ }^{11}$ Sluices by means of which low-lying ground could be inundated to form a defensive perimeter. 
The soil and subsoil is the third element in our survey of colonised ecosystems. Underground we find resources like coal, oil, gas and salt, of which in the midnineteenth century only coal was known to exist. This was mined in modest amounts in South Limburg. The top layer of the Dutch delta exhibits a variegated structure. The usual dichotomy is between the high and the low Netherlands. The high Netherlands comprises the loess grounds in the south and the sand grounds in the south and east of the country. The low Netherlands derives its soil structure from complex interactions among a rising sea level, the course of the large rivers, the formation of thick packets of peat and of fossil beach ridges and dunes. The presence of sea clay, river clay, sand and peat makes for a rich variety in soil types. For any given location the type of soil, the situation and the elevation co-determine what kind of agricultural production is possible and what kinds of fuels and minerals can be extracted. This connects the useful material flows that characterize the Netherlands around 1850 with the structure of the ground. We now provide a brief sketch of the colonisation of the soil and subsoil.

\subsection{Agriculture and Nutrition: Organic Raw Materials}

\subsubsection{Mixed Farming on the Sand Grounds}

The exploitation of the Dutch soil led to a variety of modes of agricultural extraction. ${ }^{12}$ This was due not only to the variety of soil types and their relative fertility. Tradition was also an element, especially styles of commercialization. This led to the dominance of mixed farming on the sand grounds, with a central role for the crop field. ${ }^{13}$ Manure, cattle and crop-rotation were essential to maintain fertility. ${ }^{14}$ Manure and cattle have already been mentioned (see the introduction to this chapter). A popular choice in crop rotation on the sand grounds was rye because it did well in poor soil. In Twente it was rotated with so-called catch crops like red clover, tubers and corn spurry (spergula arvensis) that were planted after the rye harvest and used as cattle fodder and to combat weeds. As 'green manure' these crops also

\footnotetext{
${ }^{12}$ See for agriculture in the Netherlands: J.L. van Zanden, De economische ontwikkeling van de Nederlandse landbouw in de negentiende eeuw 1800-1914 (dissertation Wageningen 1985); Bieleman, Boeren in Nederland; Crijns en Kriellaars, Gemengd landbouwbedrijf op de zandgronden in Noord-Brabant; Bieleman, Boeren op het Drentse zand.

${ }^{13}$ It is important to note that mixed farms on the sand grounds did not comprise a single type of system, but that they differed across time and region in the Netherlands. Hence it was possible to invest more heavily in cattle husbandry and dairy farming. Bieleman, Boeren in Nederland, 260-267.

${ }^{14}$ Cattle could be pastured on stubble fields, grasslands and heather meadows. They could also be kept in stalls, like the deep-litter stalls of North Brabant and fed on hay, tubers, spurrey and other fodder. This practice became more common at the beginning of the nineteenth century and contributed to the increase of manure production and ultimately the size of the harvests. Van Zanden, $D e$ economische ontwikkeling van de Nederlandse landbouw, 179. Another factor in increasing the size of the harvests was improved tillage thanks to intensive weeding and the use of catch crops.
} 
contributed to the restoration of soil fertility. In the province of Drenthe the rotation consisted of, for example, winter and summer rye, but also included potatoes, flax, oats and barley. In other regions, for example in North Brabant, buckwheat often replaced summer rye in the system of rotation, but potatoes and oats were also planted. A well-planned crop rotation scheme could significantly reduce the acreage that lay fallow. The way in which soil fertility was maintained differed through time and from place to place. The soil and agricultural expert, Winand Staring, distinguished six different systems on the sand grounds in 1869.

Moors, grasslands and forests were generally reckoned to the common grounds. They served as sources of peat and firewood, as pastures for sheep and so forth. The danger was overuse and the spread of sand drifts. ${ }^{15}$ Adequate management was therefore of supreme importance. The common grounds were collectively owned or open to collective use. The owners were local farmers or, as in North Brabant and Limburg, the municipalities. Sometimes the national state was proprietor. Collective management was known by a variety of Dutch names such as marken, maalschappen, holtelingen, gemeenten, boerschappen, or buurschappen. They all enforced numerous proscriptions aimed at regulating overuse and ensuring survival of these vulnerable areas. ${ }^{16}$ It was stipulated who could use the common grounds and in what way they were to be used. A board of governors decided on releasing grounds for cultivation.

Farming on the sand grounds, which consisted largely of smallholdings, was in many cases primarily oriented to satisfying the direct needs of the farmer and his family. ${ }^{17}$ It was also essential for realizing a certain surplus in order to pay taxes. And in case there was anything left over it was possible to buy goods like salt, soap, vinegar and tobacco and to invest in land, cattle and agricultural tools. The surplus was realized by selling farm products or performing work for others. In this way the farm touched on the market economy, albeit in a very limited way. The first half of the nineteenth century nonetheless witnessed an increasing orientation to the national and even international market. The sand grounds in the eastern Netherlands pioneered this development.

\footnotetext{
${ }^{15}$ After digging out the peat sods a sandy subsoil remained that could regain fertility after a time if not used too intensively. These limits were violated if peat extraction became excessive. Another excess was the pasturing of flocks of sheep, a practice that created tracks of trampled and denuded paths through the heather.

${ }^{16} \mathrm{~T}$. de Moor, The dilemma of the commoners. Understanding the use of common-pool resources in long-term perspective (Cambridge 2015). See also chapter 8 of our study.

${ }^{17}$ See: Van Zanden, De economische ontwikkeling van de Nederlandse landbouw, 145-199; Bieleman, Boeren op het Drentse zand; Van den Brink, De grote overgang, 184-192. H. Knippenberg and B. de Pater, De eenwording van Nederland (Nijmegen 1990), 98-102.
} 


\subsubsection{Grassland Farming in the Low-Lying Peat Marshes}

Exploiting the Dutch soil demanded not only heavy labour, but also cautious interventions, much knowledge, careful procedures and sound management. That was not only the case for the sand grounds. In the low-lying peat marshes of the Western Netherlands, for example, grassland farming was developed..$^{18}$ This specialized mode of farming centred on the grass and the cow. Worldwide, these areas had the highest density of cows per hectare. The quantity of milk per cow was among the highest in the world. This was due among other things to astute cattle breeding, the quality of winter fodder and the hygienic preparation of the dairy products. The growth of grass was fundamental to this type of farming and was in large measure dependent on the water level.

Managing water levels was thus a major priority and this was accomplished within the institutional framework of the polders. Authority lay with the landowners. Management was in the hands of a polder or water board council composed of polder masters or dike reeves (heemraden). Relationships, interests and procedures were laid down in regulations. By the twelfth century, cooperation among polders had already led to the formation of regional water boards. These were responsible for the construction and maintenance of hydraulic works that were shared by all the polders, for example a common drainage basin (boezem) or a sea-dike. These were often called hoogheemraadschappen. ${ }^{19}$

\subsubsection{Regional Variaty}

In this way every region had its own specific struggle with the soil and its specific institutions. The clay grounds in the central river zone were tough and nearly impermeable to water. The clay embankments were well-suited to crop farming, the low-lying grounds (so-called komgronden) by contrast, were unprofitable. Weed pollution was one of the big problems. There was the recurrent danger of dike breaches. Seepage water plagued farming in the lower lying fields. Water boards lacked the means to control the big rivers.

In the northern and southwestern coastal zones extensive dike-building had deprived the sea of its casual access to the land and had marked the start of a continual struggle between the sea and the inhabitants under the leadership of the water boards. Behind the dikes, the banks of former tidal creeks, mud flats and pools had changed into fields and grassland. New land was added to the old. Both old and new land regularly had to be surrendered to the sea again. Crop growing with a mixed farm was the dominant type, but this included all kinds of variations depending on the quality of the soil and the market conditions.

\footnotetext{
${ }^{18}$ Bieleman, Boeren in Nederland, 210-234.

${ }^{19}$ Van de Ven, Leefbaar Laagland, 69-70.
} 


\subsubsection{Market Orientation}

Market orientation also influenced how the soil was worked. Compared to farming in the eastern and southern provinces, farming in the coastal provinces (Zeeland, Holland, Friesland and Groningen) was strongly commercialized. Agriculture was therefore also more specialized. Grassland farming supplied Dutch cities and foreign countries with dairy products. North Holland was the prime cheese producing region; Friesland and South Holland were important centres of butter production. ${ }^{20}$ Making butter and cheese was the work of the farmers' wives, their daughters and the maidservants on the farm. Merchants bought butter and cheese at the farms, traded large consignments at weekly markets in nearby cities where the farmers also sold their wares, and shipped large quantities abroad, in particular to England. At the outset of the nineteenth century a quarter of London's butter and cheese market was in Dutch hands.

The mixed farm in the coastal provinces produced wheat, oats and potatoes, often destined for the market and not for use on the farm itself. The farm also produced industrial crops like rape, flax and barley. Madder was a popular industrial crop in Zeeland and South Holland. ${ }^{21}$ The roots provided a red dye used in dying and printing textiles. Extraction took place in small batches according to traditional practice in drying ovens called meestoven, usually the collective property of a number of farmers. The main elements of the process were the drying of the madder roots, their cleaning and finally pulverization. The powder was transported in large wooden barrels to the staple market in Rotterdam. Textile printers and dyers in England, the United States and Germany were important customers. Dutch madder was held in high regard and it was protected by a web of laws that, for example, specified the percentage of impurities that a certain quality of madder could contain.

Specialized, commercial agriculture also had consequences for the social structure of the countryside. ${ }^{22}$ An important difference with the sand grounds was the size of farms. Large farms (more than 20 hectares) with their hired hands and maidservants dominated in the sea clay regions in the provinces of Zeeland, Friesland and Groningen. These were also dominant in the river clay regions but less so. Smallholders were all but non-existent. Instead, there was a large population of landless farm workers and day-labourers, that was totally dependent on paid work. They earned most in the summer, less in winter, and only on days that they worked. In part they were seasonal migrant workers that relieved the shortage of farm labour at harvest and mowing time. In the provinces of Drenthe, Overijssel and North

\footnotetext{
${ }^{20}$ See for butter: M.S.C. Bakker, 'Boter', in: H.Lintsen et al. (ed.), Geschiedenis van de techniek in Nederland. De wording van een moderne samenleving 1800-1890 (Zutphen 1993), part I, 103-133.

${ }^{21}$ J.W. Schot and E. Homburg, 'Meekrap en garacine', in: H.Lintsen et al. (ed.), Geschiedenis van de techniek in Nederland. De wording van een moderne samenleving 1800-1890 (Zutphen 1993), part IV, 222-239.

${ }^{22}$ Bieleman, Boeren op het Drentse zand. Van Zanden, De economische ontwikkeling van de Nederlandse landbouw, 315-325
} 
Brabant they were in the minority. There the bulk of the rural population was composed of smallholders with one or two horses and farmworkers/smallholders without a horse but sometimes with a parcel of land and a few cows. Large agricultural enterprises with permanent farmhands also dominated in the peat marsh regions of the polders in North and South Holland with their specialized grassland farming. Inasmuch as this kind of farm was less subject to seasonal fluctuations in labour needs, these regions lacked a population of itinerant and occasional farmworkers.

Commercial farms also contracted more of their production out to specialized enterprises. Work formerly done by the farmers themselves, like spinning and weaving, were now undertaken by specialized businesses and persons. In consequence the commercial farming regions had a more differentiated occupational structure and a larger contingent of specialized craftsmen.

\subsubsection{Food Supply}

Dutch soil produced a cornucopia of agricultural products. These products were not subject to extensive processing. ${ }^{23}$ Potatoes and vegetables were pretty much cooked as is. Wheat had to be ground and bread had to be baked. Milk was drunk straight from the cow, utilized in porridge, churned and turned into butter and cheese. Consumption of dairy products was, however, limited. There was little variety in foodstuffs, at most a few hundred different products. The Dutch above all ate what was locally produced. Culinary culture differed according to social class, region, season and between town and country.

Food processing was done on a small-scale, traditional basis, largely in the household. Sources of energy were classic and consisted of muscle power (of humans, horses and dogs), wind energy throughout the country and water power in some areas, and warmth provided by peat, wood or coal. Tools were made of wood and metal, and simple enough that the local carpenter or smith could make, repair or imitate them. Craft knowledge was transmitted from father to son, from mother to daughter, from master to apprentice and was further developed in practice. The distance between producers and consumers was small. The Dutchman bought directly from the farmer or the baker, at day or week markets or in small speciality shops. Food supply was above all bound to the rules of the local occupational communities and the municipal governments.

In addition to agricultural products, the soil and especially the subsoil of the Netherlands also produced fuel and minerals. We will now turn to these.

${ }^{23} \mathrm{H}$. Lintsen et al., Made in Holland. Een techniekgeschiedenis van Nederland [1800-2000] (Zutphen 2005), 38. 


\subsection{Building Materials and Construction: Mineral Resources}

Clay, sand and gravel were the voluminous building materials for hydraulic engineering, road building and housing and building construction. But little could be done with only clay, sand and gravel. Many other building materials were necessary and these came in large part from abroad. ${ }^{24}$ Wood was an important building material. Oak and pine were supplied from Germany via the Rhine. Scandinavia, the Baltic Sea harbours and Russia supplied softwoods like pitch pine and fir. Rocks were obtained from Germany (sandstone) and Belgium (basalt). Mortars were imported from the Belgian Meuse basin (chalk) and the German Eifel (trass cement). Fired shell chalk, another mortar, could be produced in the Netherlands itself by trawling for shells along the coast. With these and a few other materials like iron and asphalt, the Netherlands was able to carry on.

Many Dutchmen were in practice hydraulic engineers, because the local population, especially the farmers, were responsible for the maintenance of dike sections, digging drainage ditches, building simple sluices and so forth. This was inadequate for larger infrastructural works (canals, river works, coastal defences and such). ${ }^{25}$ Here so-called polder workers commonly did the heavy labour of digging and transporting clay and sand. They came from the countryside and arrived en masse with their spades and wheelbarrows when a major work was set to start. Complex hydraulic projects involved all kinds of trades and technical specialists like carpenters, masons and engineers. ${ }^{26}$

Road building also depended on the local population, and in particular on farmers, workers and contractors. Local roads were simple and were made of clay, sand or peat. Sometimes they were surfaced with rubble or shells. ${ }^{27}$ In addition there were hardened roads generally built under central government supervision. First the

\footnotetext{
${ }^{24}$ W. van Leeuwen, 'Woning- en utiliteitsbouw', in: H. Lintsen et al. (ed.), Geschiedenis van de techniek in Nederland. De wording van een moderne samenleving 1800-1890 (Zutphen 1993), part III, 197-198.

${ }^{25}$ W. van Leeuwen, 'Waterbouw', in: H. Lintsen et al. (ed.), Geschiedenis van de techniek in Nederland. De wording van een moderne samenleving 1800-1890 (Zutphen 1993), part III, 231-236.

${ }^{26}$ Building shipping locks and sluices was above all work for carpenters and masons. Wood was much used because the lock was primarily a wooden construction with wood for the lock gates, the sills, the foundations, 'eel planks' (contiguous wooden pilings placed at right angles to the lock axis to prevent seepage of water under the sills), etc. The construction site also sported other trades like pile drivers, smiths, laborers, contractors and sometimes even an engineer. Every type of hydraulic infrastructure had its own specialists. In dike construction, for example, willow workers made fascine mattresses that served to protect shorelines under water. A fascine mattress was a rectangular grid of bundles of brushwood filled in with reeds or willow twigs. On completion, the mattress was towed to its destination, ballasted with heavy stones and sunk to the bottom.

${ }^{27} \mathrm{~A}$ worn-in wagon track determined the profile of the road. The clay and peat roads were transformed into impassable mud-mires in the winter and after periods of heavy rain in other seasons. The sand roads were reasonably passable in winter but became loose sand in the summer.
} 
existing ground was excavated and replaced by a layer of sand. On top of this a hardened road was built, usually composed of Dutch clinker bricks. ${ }^{28}$

Water management and infrastructure in the Netherlands were traditionally the responsibility of local interests (water boards and farmers) municipal and provincial governments and sometimes private investors. In the first half of the nineteenth century the national government, and in particular King William I, initiated the construction of comprehensive road and waterway networks and other infrastructural works. Provinces, municipal governments and water boards generally played a subsidiary role. The works contributed significantly to Dutch state formation.

In housing construction, new houses were built with a skeleton of brick loadbearing walls, wooden floors and beams, slate or baked roof tiles and forged iron wall anchors. ${ }^{29}$ These techniques were applied to a wide variety of housing ranging from workers' homes, through middle-class homes, to mansions, urban villas and country estates. There was also a wide variety of non-residential buildings in the government sector (prisons, university buildings, covered markets, assembly halls), the private sector (among others warehouses, office buildings, workshops and hotels) and the semi-private sector (for example churches, theatres and exhibition halls). While these buildings were more or less complex - some might even be considered daring - they were for the most part traditional stone and wood structures. Other materials were limited to chalk, glass, paint, forged iron and stone.

Carpenters and masons were the most important craftsmen. They were part of a rich palette of craftsmen that could be encountered at a construction site, such as painters, stone masons, glaziers, decorators and slate roofers. There were also unschooled workers like porters and pile drivers. Part of the construction work force was employed by suppliers of materials, like sawmills and brick factories. The organization of a construction project was in the hands of a contractor who had learned by doing, generally as a carpenter or mason. Big projects might be managed by an architect or engineer.

Housing for workers comprised the majority of buildings. They hardly deserved the name. In the cities they took the form of slums built of stone and wood. On the edges of cities, in the countryside and in smaller towns one found numerous huts and underground burrows. ${ }^{30}$ Walls were erected of lath, pine branches, and stones and filled in with clay, loam and horse manure. Roofs were covered with reeds. Burrows were dug in the ground. Huts were built of dried peat. The fireplace was a depression in the ground. Smoke escaped through a hole in the roof.

\footnotetext{
${ }^{28}$ Rainwater could easily drain through the layer of sand and the hard bricks did not sink into the subsurface after rainfall. The total width of the road was 8 to 10 meters, of which about half was paved.

${ }^{29}$ W. van Leeuwen, 'Een complexe sector', in: H. Lintsen et al. (ed.), Geschiedenis van de techniek in Nederland. De wording van een moderne samenleving 1800-1890 (Zutphen 1993), part III, 192. ${ }^{30}$ See among others: A. van der Woud, Koninkrijk vol sloppen. Achterbuurten en vuil in de negentiende eeuw (Amsterdam 2010), 82-84.
} 


\subsection{Energy: Fossil Fuels}

The extensive peat bogs that covered large parts of the Netherlands were a ready source of peat turf. Turf - a dried form of peat - represented a revolution in the domain of energy that had taken place as early as the late middle ages. From that time the country burned its own ground in order to produce, to cook and to warm itself..$^{31}$ The annual average temperature was $9^{\circ} \mathrm{C}$ and the winters were often bitterly cold. Turf was used in households for heating and cooking. Industry too was an important market. Beer breweries, chalk ovens, cotton printing mills, dye works, bleaching works and brick factories were the biggest users. Their fuel was turf and that would remain the case for centuries.

Dutch cities had a long history of dependency on turf. ${ }^{32}$ Originally it was easily accessible in nearby surrounding peat bogs. ${ }^{33}$ By the eighteenth century production had moved to the northeast. ${ }^{34}$ The scale at which this took place required so much capital and was fraught with such risks that companies (compagnieën) were formed. These were consortiums, partnerships, in which anyone could invest and become stockholder, participant, partner or associate. Because it took a considerable time before these investments returned a significant profit, the companies were dominated by very wealthy investors from the province of Holland. Groningen was an exception. The city succeeded in retaining control over turf extraction in its region.

\footnotetext{
${ }^{31}$ See for this among others: T. Stol, 'Turfwinningslandschap', in: S. Barends, Het Nederlandse Landschap. Een historisch-geografische benadering (tenth revised edition, Utrecht 2010), 114-131.

${ }^{32}$ Economic prosperity in the Netherlands in the seventeenth century was in part due to the presence of this cheap source of energy in the immediate surroundings. Without turf the Golden Century would have been a more difficult business. Many activities were able to flourish thanks to this brown gold. Alternative fuels were available abroad, but at a higher price. Turf survived the Golden Century. Historians are of divided opinions on the meaning of turf in the Golden Century. According to J.W. de Zeeuw, turf was essential for economic success. See: J.W. de Zeeuw, 'Peat and the Dutch Golden Age. The historical meaning of energy attainability', AAG Bijdragen 21(1978), 3-32. J.L van Zanden takes a middle position. Other scenarios with less turf and more coal and firewood also led to a successful economic development. See: J.L. van Zanden, 'Werd de Gouden Eeuw uit turf geboren. Over het energieverbruik in de Republiek in de zeventiende en achttiende eeuw', Tijdschrift voor Geschiedenis 110 (1997), 484-499. Van Zanden writes not so much about a more difficult but rather about a different story for a Golden Century without turf.

${ }^{33}$ Originally peat extraction took place above the level of groundwater, so-called dry extraction. Once this supply was used up, wet extraction had to be employed. Working from a boat or a plank, the peat was dug out of the water with a dredging hook and dumped in a boat. The peat was subsequently unloaded on a laying field or dam, spread out, compacted, dried in the open air, pressed into forms, piled up, dried some more and finally sold as turf. Wet extraction was practiced until the seventeenth century above all in South Holland and the western part of Utrecht, in addition to the northern provinces.

${ }^{34}$ This displacement was part of the spread of the peat colonies. These began in Flanders and spread from there to northwest Brabant (thirteenth century), the Valley of Gelderland and Friesland (sixteenth century), Groningen (seventeenth century) and the Peel region (nineteenth century). Techniques and organization improved with each displacement.
} 
Extraction was systematically executed with main canals, locks and bridges and additional infrastructure in the form of parcels, ditches and so forth. The turf was extracted mainly 'in the dry.' The top layer, the bonkaarde or bolster, had little value as fuel, but was later mixed with the infertile sand ground that was a common by-product of turf extraction. The bonkaarde provided an improved soil structure with better hydrological properties. It was in fact the point of departure for the system of mixed farming, with cattle providing the manure. Urban waste also served as fertilizer. The turf ships transported this commodity as return freight.

Turf production reached its zenith in the nineteenth century. Expansion of turf extraction in the north eastern provinces of Drenthe and Overijssel was made possible by the digging of a new canal, the Dedemsvaart (1809). A bit later the Peel region spanning the border between the southern provinces of North Brabant and Limburg was likewise made accessible for turf extraction by a new canal called the Zuid-Willemsvaart (1826). Official statistics indicate that in 1850 the Netherlands burned 2.5 million tons of turf. ${ }^{35}$ This comes down to $750 \mathrm{~kg}$ of turf per capita. To this must be added the turf that residents of the countryside extracted for their own use from nearby peat bogs. Ultimately turf lost out as a fuel to ever-cheaper coal.

\subsection{Natural Capital and Material Flows}

Around 1850, the exploitation of the Dutch soil and subsoil produced an overseeable number of raw materials. Our point of departure is the three main categories of this study: bio-raw materials, subsoil fossil assets, and subsoil mineral assets. A reconstruction on the basis of official statistics reveals the following pattern (see Table 3.1). ${ }^{36}$ The three categories together totalled an estimated 8390 kilotons in 1850 (domestic production). Bio-raw materials accounted for 4.670 kton (56\%), subsoil fossil assets for $2520 \mathrm{kton}(30 \%)$, and subsoil mineral assets for $1200 \mathrm{kton}$ (14\%).

Within these categories, six products were especially prominent: cereals, potatoes and dairy products (bio-raw materials), turf (subsoil fossil assets) and clay and sand (subsoil mineral assets). The three agricultural products totalled $3430 \mathrm{kton}$ (amounting to $41 \%$ of total domestic production). Turf totalled 2500 kton and accounted for $30 \%$ of the grand total. For clay and sand this amounted to $1150 \mathrm{kton}$

\footnotetext{
${ }^{35}$ See Table 3.1. The caloric value of 2,5 million tons of turf is somewhere between 15,000 and $38,000 \mathrm{TJ}$. The caloric value of moist turf is $6 \mathrm{MJ} / \mathrm{kg}$ and of dry turf $15 \mathrm{MJ} / \mathrm{kg}$. The caloric value (in other words the specific energy or energetic value) is a measure of the energy-content of a fuel. Hölsgens calculates an energy consumption of turf in 1850 of 22,000 TJ (five-year average). H. N.M. Hölsgens, Energy transitions in the Netherlands. Sustainability challenges in a historica land comparative perspective (Dissertation RU Groningen 2016), Appendix I, 213.

${ }^{36}$ The table provides only a rough indication. The figures provide an order of magnitude that is estimated and checked in different ways. It is probable that a more accurate calculation of the figures will not result in remarkable shifts in most of the (sub)categories. This is not the case for some categories like vegetables from vegetable gardens and brushwood, because these are not officially registered. In subsequent analyses we shall have to keep such unofficial material flows in mind.
} 
Table 3.1 Raw materials in the Netherlands around 1850 in kilotons

\begin{tabular}{|c|c|c|c|c|c|}
\hline & & $\begin{array}{l}\text { Domestic } \\
\text { production }\end{array}$ & Import & Export & Available \\
\hline \multirow{18}{*}{$\begin{array}{l}\text { Bio raw } \\
\text { materials }\end{array}$} & Crops/market garden & 2,040 & 290 & 200 & 2,130 \\
\hline & Potatoes & 790 & 10 & 20 & 780 \\
\hline & Cereals & 670 & 180 & 100 & 740 \\
\hline & Beans & 80 & $<5$ & 10 & 80 \\
\hline & Fodder beets etc. & 60 & $<5$ & $<5$ & 60 \\
\hline & Oil seeds \& oil & 40 & 40 & 10 & 70 \\
\hline & Misc. Agr. Prod. & 400 & 60 & 60 & 400 \\
\hline & Cattle farming & 2,220 & 10 & 80 & 2,150 \\
\hline & Milk & 1,970 & $<5$ & $<5$ & 1970 \\
\hline & Living animals & 250 & 10 & 80 & 180 \\
\hline & Eggs & $<5$ & $<5$ & $<5$ & $<5$ \\
\hline & Miscellaneous & $<5$ & $<5$ & $<5$ & $<5$ \\
\hline & Fishing \& hunting & 210 & $<5$ & 30 & 180 \\
\hline & Fish & 130 & $<5$ & 30 & 100 \\
\hline & Shells & 80 & $<5$ & $<5$ & 80 \\
\hline & Forestry & 200 & 290 & 10 & 480 \\
\hline & Timber & 150 & 290 & 10 & 430 \\
\hline & Firewood & 50 & $<5$ & $<5$ & 50 \\
\hline \multirow{3}{*}{$\begin{array}{l}\text { FOSSIL } \\
\text { Sub-soil } \\
\text { assets }\end{array}$} & Fossil sub-soil assets & 2,520 & 540 & 30 & 3,040 \\
\hline & Turf & 2,500 & 10 & $<5$ & 2514 \\
\hline & Coal & 20 & 530 & 30 & 518 \\
\hline \multirow{8}{*}{$\begin{array}{l}\text { Mineral } \\
\text { Sub-soil } \\
\text { assets }\end{array}$} & $\begin{array}{l}\text { Mineral sub-soil } \\
\text { assets }\end{array}$ & 1,200 & 150 & 20 & 1,330 \\
\hline & Clay & 650 & 20 & 10 & 660 \\
\hline & Sand & 500 & $<5$ & $<5$ & 500 \\
\hline & Gravel & 40 & $<5$ & $<5$ & 40 \\
\hline & Stone & $<5$ & 80 & $<5$ & 80 \\
\hline & Salt & $<5$ & 40 & $<5$ & 40 \\
\hline & Ore & 10 & $<5$ & $<5$ & 10 \\
\hline & Total & 8,390 & 1,280 & 370 & 9,300 \\
\hline
\end{tabular}

Remark: Sand for heightening ground and dike clay are not included in the table

Source: F. Lambert, Massastromen in Nederland. in de jaren 1850, 1913, 1970, 2010 (research rapport Technische Universiteit Eindhoven, oktober 2016)

and $14 \%$. The remaining $15 \%$ consisted of a great number of other products: oil seeds, beans, wood, gravel and so on.

The Netherlands was for the most part self-sufficient. Of all the raw materials available to the Netherlands (domestic production plus import, totalling $9670 \mathrm{kton}$ ), only a small portion came from outside the country (1280 kton, 13\%). In terms of weight this was above all coal (about 500 kton, or 6\%), wood (about 300 kton, or $3 \%$ ) and cereals (about 200 kton, or 2\%). Nevertheless, the fact remains that the 
Netherlands depended on other countries for its coal, while the foreign share of timber (for construction) and cereals (for food) was substantial.

This pool of raw materials gave rise to overseeable material flows. ${ }^{37}$ The Dutch population directly consumed an important part of the agricultural produce and that virtually all the fossil raw materials (turf and coal) were directly burned (in households and industry). That took place without much preliminary processing. A smaller portion of the agricultural produce was processed in the food industry by grain millers, bakers, butchers and other artisans, while shell-chalk ovens transformed shells into quicklime and sawmills processed wood for use in constructions and buildings. Only a small portion was used directly, for example as firewood. Direct end-use also applied to some extent to mineral raw materials (for example the use of sand in building construction). On the other hand, a significant portion of the clay was used by the brick industry to form and bake bricks. As far as export goes, agricultural and food products dominated: wheat, cattle, sugar, butter and cheese.

In addition to these major flows there were a great number of smaller material flows - not visible in the table and the figure - for example imports of coffee, tea and cane sugar from the colonies (especially the Dutch Indies). When these lesser flows are taken into account, domestic agriculture suddenly appears to deliver a greater variety of products, like hops and madder. Then too, there were raw materials that were never registered despite their importance. Sand for raising the ground level and clay for dikes represented a considerable mass in certain periods but were not registered in the statistics. ${ }^{38}$ These materials were usually obtained in the immediate vicinity and were, among other things, used to build railway embankments and

\footnotetext{
${ }^{37}$ See for the details of material flows in 1850 the open-access publication: F. Lambert, Massastromen in Nederland. In de jaren 1850, 1913, 1970, 2010 (researchrapport Technische Universiteit Eindhoven, oktober 2016)., 11-17.

${ }^{38}$ The most important infrastructural works around 1850 were:

- Railways

1845 construction line Driebergen - Arnhem, Dutch Rhine Railway, $50 \mathrm{~km}$

1847 construction line The Hague - Rotterdam, $25 \mathrm{~km}$

1853 construction line Maastricht - Aachen, $40 \mathrm{~km}$

1854 construction line Essen (B) - Zevenbergen/Etten Leur, 48 km

1855 construction line Utrecht - Rotterdam, $60 \mathrm{~km}$

Railway construction: $23 \mathrm{~km}$ per year average

Embankments about $8 \mathrm{~m}$ wide $-1 \mathrm{~m}$ high: $184.000 \mathrm{~m}^{3}$ (sand to make elevation) $* 1600 \mathrm{~kg} / \mathrm{m}^{3}=\mathrm{ca}$. 300 kton.

- Reclamation Haarlem Lake (1840-1852):

Dikes Haarlem Lake - the encircling dikes $(60 \mathrm{~km})$ are completed in $1848(7.5 \mathrm{~km}$ per year). $7.5 \mathrm{~km}$ per year $15 \mathrm{~m}$ wide, $2.50 \mathrm{~m}$ high $= \pm 280,000 \mathrm{~m}^{3}$ (dike clay) $* 1800 \mathrm{~kg} \cdot \mathrm{m}^{3}= \pm 500 \mathrm{kton}$.

- A conservative estimate for the period around 1850 comes out at about 800 kton of sand and dike clay.

- Not included are:
}

Excavations due to differences in elevation (railways).

Expansion of cities and towns. 
Table 3.2 Contribution of economic clusters to GNP and employment rates in the Netherlands around 1850 (percentages)

\begin{tabular}{l|l|l}
\hline & $\begin{array}{l}\text { GNP (1850) (fl. 560.9 } \\
\text { million) }\end{array}$ & $\begin{array}{l}\text { Employment (1849) } \\
\text { (n=1,270,764) }\end{array}$ \\
\hline Agriculture and foods & 36 & 44 \\
\hline Construction and housing & 8 & 7 (construction) \\
\hline Textiles and clothing & 7 & 10 \\
\hline $\begin{array}{l}\text { Trade, distribution, } \\
\text { transport }\end{array}$ & 30 & 14 \\
\hline Other & 19 & 35 \\
\hline Total & $100 \%$ & $100 \%$ \\
\hline
\end{tabular}

Source: J.P. Smits, E. Horlings and J.L. van Zanden, Dutch GNP and its components, 1800-1913 (Groningen 2000), Table 4.5 and Table B.1

canal dikes. Growing vegetables in one's own vegetable patch and collecting brush wood for firewood were also not included in the statistics. Another such category was the domestic fabrication of clothing using wool or flax grown on the farm.

Two main flows dominated economic activity: first, agriculture-food-food consumption and, second, mineral raw materials-mineral processing-construction. The most important points of production were the farm, the brick factory and the construction site. These locations processed the bulk of raw materials. The farm produced above all potatoes, cereals, milk, butter and cheese. The brick factory delivered bricks. At construction sites building materials were transformed into houses, roads, dikes and other constructions. From this perspective, the Netherlands was above all an agricultural and building country.

Table 3.2 in part reflects this conclusion. The share of agriculture and foods in the GNP was $36 \%$ and in employment $44 \%$. For construction and housing these percentages were respectively $8 \%$ and $7 \%$. Trade, distribution and transport also constituted an important category with $30 \%$ of the GNP and $14 \%$ of the employment. Their economic contribution was however also realized to a large (but unknown) extent within the categories of agriculture, foods and construction. One would hardly expect textiles and clothing with their modest mass flow to be so prominent in the table with respectively $7 \%$ and $10 \%$. Despite their relatively low weight, they scored high in the statistics in terms of money and expended labour.

In general the supply chains of raw material production, processing, use, export and transport were short. The statistics do not show the fact that the supply chains of bio-raw materials and mineral subsoil assets were predominantly closed cycles. At the end of the chain, agriculture and food produced animal and human faeces. These were collected, mixed with fireplace ashes and organic waste (derived from vegetables, fruit and vegetable patches), made into compost and sold to farmers as fertilizer. In this way urban manure contributed to the fertility of the soil. The collection of manure and faeces was unremarkable in a period in which many materials were re-used. ${ }^{39}$ Many Dutch people, for example, bought their clothes

\footnotetext{
${ }^{39}$ Lintsen et al. (ed.), Made in Holland (Zutphen 2005) 56-58. See also: A. Oudejans, Categorie één.. Dierlijke afvalverwerking door de eeuwen heen, 27-32.
} 
second-hand at the market. Once worn out, the clothing was used in the production of paper. Bones were collected to make glue. Building materials from demolished houses were used anew, while building rubble served as pavement material and to heighten building plots.

Matters were otherwise in the case of fossil subsoil assets. ${ }^{40}$ Here we find a predominantly linear supply chain. Turf and coal were transformed into heat upon combustion. ${ }^{41}$ Nowadays coal is reckoned to be a non-renewable resource. In this study we shall do the same for turf, even though the formation of peat as the basis for turf production is an immeasurably more rapid process than the formation of coal, namely several decades. ${ }^{42}$ The total energy consumption of the Netherlands for 1850 can be estimated at 88,500 Tera joule (TJ), including not only turf and coal, but also muscle power, wood, wind and water as sources of energy. 36,200 $\mathrm{TJ}$, or $41 \%$, were supplied by turf and coal; the rest $(52,300 \mathrm{TJ}$ or $59 \%)$ from renewable sources. Discounting human muscle power, the share of renewable energy was $52 \% .^{43}$

The economy of the Netherlands in those days could justifiably be regarded as circular. To what extent was it also sustainable in terms of today's concepts? We answer this question in Chap. 6, 'Well-being and sustainability around 1850: the frame of reference.'

The natural capital of the Netherlands is described here in terms of the colonisation of water, air and ground (soil and subsoil). On the one hand the colonisation had consequences for the country's dead and living nature. This is the topic of the next section. On the other hand the colonised ecosystems produced raw materials and the material flows that derived from them. These were the foundations for economic development (see the concluding section) and the quality of life (see the next chapter).

\footnotetext{
${ }^{40} \mathrm{H}$. Hölsgens, Energy transitions in the Netherlands. Sustainibility Challenges in a historical and comparative perspective (dissertation Rijksuniversiteit Groningen 2016), 5-13 and appendix I: Energy consumption in the Netherlands (1800-2012).

${ }^{41}$ Ashes from burned turf were employed as an agricultural fertilizer. This can be seen as a form of recycling.

${ }^{42}$ Turf production was much smaller than the total energy consumed. Contemporaries hence regarded turf as a non-sustainable energy source (i.e. as non-renewable). See Hölsgens (2016) forthcoming in Tijdschrift voor Economische Geschiedenis.

${ }^{43}$ For 1850: total consumption $(88,466 \mathrm{TJ})$, total human muscle power $(12,661.9 \mathrm{TJ})$, total consumption excluding human muscle power (75,803.9 TJ). This new total includes 36,162 TJ/48\% turf and coal and 39,642 TJ/52\% renewable. Information R. Hölsgens (see previous note).
} 


\subsection{A Variegated Landscape}

\subsubsection{Biodiversity}

In this study natural capital occupies a special position with respect to other forms of capital (economic, human, and social). It is the basis of production, consumption and well-being. Aside from this utilitarian function, natural capital also has an intrinsic value. This was referred to in the introduction as ecological well-being and is a measure of the quality of living and non-living nature. This intrinsic value does not depend on the contribution of natural capital to the well-being of humans. Nonetheless it is often associated with quality of life. Positive ecological well-being is considered good for fresh air, pure water, plant pollination, sustainable agricultural production, storage of $\mathrm{CO}_{2}$, et cetera.

What was the impact of the colonisation of nature on ecological well-being in the Netherlands? In the sustainability monitor, ecological well-being is reduced to biodiversity, expressed by the indicator 'Mean Species Abundance' (MSA). What does this indicator tell us? MSA starts with a natural ecosystem that has not yet been disturbed by human activity, and takes the species diversity in that situation as its point of reference. ${ }^{44}$ Intervention by humans causes a decline in biodiversity, that is, in the original variety of species. A region with an MSA of $100 \%$ means that biodiversity there is the same as the natural ecosystem. A region with an MSA of $0 \%$ is equivalent to a thoroughly colonised ecosystem, such that the original biodiversity has completely disappeared. The simplest method of calculation of an MSA is based on the land use of a given region. On this approach the transformation of a natural ecosystem into grassland reduces biodiversity by a factor of 0.3 ; into a field of crops by a factor of 0.7 ; and into an urban area by a factor of 0.95 . More nuanced calculations are not possible for the nineteenth century due to a lack of data. It is however certainly remarkable that the heathlands, also known as the 'wastelands,' do not form a separate category in the method of calculation and are treated as a natural ecosystem. ${ }^{45}$ This despite the fact that in the Netherlands an agricultural landscape was created on the basis of grazing the wastelands and the use of peat sods to improve their sandy soils. In 1850 about a third of the country consisted of heathlands. In the conclusion we will return to this shortcoming.

\footnotetext{
${ }^{44}$ J.L. Van Zanden et al., How was life? Global well-being since 1820 (OECD n.pl. 2014), 182. This source is based on: R. Alkemade, M. van Oorschot, L. Miles, C. Nellemann, M. Bakkenes and B. ten Brink, 'GLOBIO3: a framework to investigate options for reducing global terrestrial biodiversity loss', Ecosystems 12(2009), 374-390 and K. Goldewijk, 'The HYDE 3.1 spatially explicit database of human-induced global land-use change over the past 12,000 years', Global Ecology and Biogeography 20(2011), nr. 1, 73-86. Voor de definitie van MSA: Alkemade et al., 'GLOBIO3', 375 .

${ }^{45}$ The terms 'heather' or 'moorland' (heide) do not appear in the publications cited in the previous note. The publication by Alkemade et al. (2009 GLOBIO3, 379) attributes 'scrublands' (e.g. steppe, tundra or savannah) to the category of natural ecosystems. It may be the case that they also include heathlands or moorlands in this category. In some settings heathlands may be a natural ecosystem but that is not the case in the Netherlands.
} 
We can estimate the MSA for the Netherlands around 1850 at $73 \%$. What does this figure mean? It would indicate that the Netherlands possessed $73 \%$ of the biodiversity that existed before human influence in the various parts of the country became noticeable. We will return to this at the end of this section. First we want to give an impression of the big changes in the ecosystems of the sand grounds and the maritime zones. The Dutch forests, at least what was left of them, will be treated separately.

\subsubsection{The Sand Grounds}

Agriculture had thoroughly transformed the landscape of the sand grounds. ${ }^{46}$ When human influence was still minimal - in the sixth and fifth millennium BC - the sand grounds were covered with extensive forests of, among other species, Scottish pine, birch, oak and alder. ${ }^{47}$ The agricultural landscape of 1850 revealed little of this. What remained were isolated bits of forest, especially in the stream valleys and in remote spots, bits whose survival was constantly threatened. They were thoroughly integrated into the farming system. Cattle were tended there. Their wood was gathered and used for fuel (heating and cooking) or served as building material (furniture, clogs, tools, machines, load bearing constructions for farm buildings, etc.)

Crop fields, heath, grazing pastures and hayfields had taken the place of the forests. By today's standards the agricultural system had a rich ecology. ${ }^{48}$ Heather and cross-leaved heath dominated the heath-fields. Birches and oaks were scattered here and there. Orchids, gentian and bog asphodel prospered, depending on local soil conditions. Bluegrass (Cirsio dissecti-Molinietum), an unusually biodiverse kind of poor meadow and hay land that existed in the infertile damp meadows in the stream valleys, sported plants that are now extremely rare: plants like the devil's bit, marsh violet, sundew and meadow thistle. The low-lying, saturated or wet stream dales were home especially to the forests, dominated by alder, willow and ash and in which one could find forest plants like the wood anemone, lily of the valley, and blueberry.

A characteristic element of the landscape was the wooded banks. They were built along paths, around fields and along pastures. As an enclosure the wooded bank was impermeable to cattle, as fencing it enabled the farmer to mark the extent of his

\footnotetext{
${ }^{46}$ The nature of the original Dutch landscape, that is the landscape before human influence made itself felt, is a matter of controversy. Was the Netherlands largely forested or was it an open landscape with large herds of grazing animals? In this section we assume a forested landscape. For the debate see: L. Kooijmans, 'Holland op z'n wildst? De Vera-hypothese getoetst aan de prehistorie', De Levende Natuur 113(2012), nr. 2, 62-66.

${ }^{47}$ For an exhaustive description of the landscape of the sand grounds see: J.A.J. Vloet, 'Zandlandschap', in: S. Barends et al., Het Nederlandse Landschap. Een historisch-geografische benadering (tenth revised edition, Utrecht 2010), 132-161; Thijs Caspers, De hand van de mens in het landschap (Haaren 1992); Natuur in Noord-Brabant. Twee eeuwen plant en dier (Haaren 1996).

${ }^{48}$ For this see: Caspers, De hand van de mens, 49-56; Natuur in Noord-Brabant. Twee eeuwen plant en dier (Haaren 1996), 28-71.
} 
property and as means of production the bank supplied fruits, berries, firewood and wood for construction. A wooded bank consisted minimally of a deep ditch with a contiguous earthen bank on which grew trees, bushes, plants and herbs. Small mammals (mice, weasels and stoats) found forage there or used it as cover during their forays (the badger). Many birds found the wooded bank a congenial biotope because it provided cover, good nesting sites and a wealth of insects, fruits and berries. Wooded banks ran like green veins through the sand grounds and provided sharp contrasts in the landscape: the leafy environs of many villages and stream valleys over against the broad empty spaces of the heath meadows.

The heath meadow was a vulnerable component of the landscape. ${ }^{49}$ It was constantly threatened by overexploitation. Heath meadows were once themselves the result of overexploitation. After forests had been felled and the land exhausted by farming, heather was one of the few species that could survive on the poor sand grounds that remained. The cutting of heather sods for the production of compost and manure exposed the bare sandy subsoil. ${ }^{50}$ Where things got out of control and the sand got the upper hand, sandstorms threatened fields and villages and sand deserts like those on the Veluwe and in Noord Brabant (the Loon and the Drunen Dunes).$^{51}$ The question is to what extent the farming community lost its grip on the process. The danger lurked in growing population pressure and the consequent increase in cultivated acreage and more intensive use of the common lands, including the heath meadows. That was exactly the situation in the first half of the nineteenth century, with its rapid increase in rural population. At some places this did indeed cause problems. Nonetheless there are no indications that in general things took a dramatic turn for the worse. ${ }^{52}$

\subsubsection{The Maritime Zones}

Prior to the arrival of the first farmers in the fourth and third millennium BC, the northern and southwestern maritime zones bore a strong resemblance to the present day Wadden Sea and the parts of the Wadden islands now outside the dikes. ${ }^{53}$ The

\footnotetext{
${ }^{49}$ The heath meadows belonged to the so-called communal lands or the 'commons'. This is the subject of an extensive literature, see: T. de Moor, The Dilemma of the Commoners: Understanding the Use of Common Pool Resources in Long-Term Perspective (Cambridge 2015).

${ }^{50}$ Another form of excessive exploitation was the pasturing of sheep, a practice that left traces of trampled and denuded paths across the heather.

${ }^{51}$ This was a troublesome phenomenon for the farmer. Crop fields and pastures were buried in sand drifts. Even buildings in the villages were threatened. To keep the advancing sands at bay, wood banks had to be raised, grey hair grass planted, ditches dug etc. Around 1850 the problem seemed to be reasonably under control. Caspers, De hand van de mens, 60-61.

52 J. Renes, Landschappen van Maas en Peel (Maastricht 1999), 203-204. See also Chap. 8 of our study.

${ }^{53}$ For the following see: L. Hacquebord, 'Noordelijk zeekleilandschap', in: S. Barends, Het Nederlandse Landschap. Een historisch-geografische benadering (tenth revised edition, Utrecht
} 
extensive tidal flats consisted of higher mud and sand ridges, tidal creeks, accreted silt from shore erosion, salt swamps and dunes. Species diversity was low because few plants could cope with the extreme conditions of the salty environment and the changing water levels. The tidal flats became the province of salt-tolerant plants common to brackish environments. ${ }^{54}$ Seaweed, glasswort, and herbaceous seepweed grew on the mudbanks (slikken, i.e. low-lying sediment ridges that were regularly flooded), while for example the salt meadows (schorren, or high sediment ridges that only flooded at spring tides or during storm surges) were the domain of sea poa and sea lavender. Large numbers of migratory, overwintering or resident birds like brent geese, waders, avocets and spoonbills found nourishment, rest, and breeding grounds here. Throughout most of the Middle Ages these maritime zones retained this characteristic landscape.

In the first half of the nineteenth century the sea-clay landscape must have been considerably more diverse than the formerly un-diked land due to the variation between wet and dry, salt and fresh, clay and sand, dike and polder. Mud banks and salt meadows, geese and avocets were still part of this landscape, but now joined to various other landscape elements. In addition to the fields and the meadows, for example, there were now also the brackish polders with their pools and watering holes. ${ }^{55}$ They were used as extensive grasslands and were home to salt-tolerant plants like wild celery and brackish dropwort as well as salt-intolerant plants like orchids and the greater yellow rattle.

The dikes also exhibited a variegated vegetation that was sometimes so profuse that they were called 'flower dikes.' This was due in part to grazing by itinerant flocks of sheep. Other important factors were the composition of the dike and the pitch of the slope that determined the position of the plants relative to the sun. Typical plants were, among others, wild marjoram, tuberous pea, wild onion and eryngo. Sometimes dikes were planted with willows and poplars.

Bramble hedges of hawthorn, blackthorn, dog rose, or blackberries were quite common. They served as fencing for fields and as a congenial biotope for insects, amphibians, birds and other animals. The hedges provided them with shelter, food and nesting sites. And then every region had its own characteristic elements like the numerous lakes in Friesland and the inlagen in Zeeland, small polders containing reed marshes and ponds that lay between the sea dike and a 'secondary dike' that had been created for the purpose of salt mining.

2010), 16-31 and A.P. de Klerk, 'Zuidwestelijk zeekleilandschap', in: S. Barends, Het Nederlandse Landschap. Een historisch-geografische benadering (tenth revised edition, Utrecht 2010), 32-45.

${ }^{54}$ Additional information on flora and fauna can be found on different websites, among others: www.natuurinformatie.nl; www.natuurkennis.nl en www.zwinstreek.eu

${ }^{55}$ Information on flora and fauna can be found on different websites, including: www.hetzeeuwselandschap.nl; www.deturfhoeke.nl 


\subsubsection{The Lost Forest}

A resource that the inhabitants of the delta had long since exhausted was the forest. Around 1850 forest acreage had been reduced to a minimum of 5\% of the Dutch surface area. There was a time when large parts of the Netherlands had been covered with forests of many sorts: alluvial forests, swamp forests, heron forests, dune forests etc. In the course of time they fell prey to the expansion of agriculture, turf extraction, wars and storms. The forests that survived were constantly threatened by overexploitation. Forests produced fruits, served as pasture for cattle and were royal repositories of fuel and construction material. Certain species of trees had survived agricultural expansion better than others. On the sand grounds, for example, the summer oak's thick bark had enabled it to survive the slash and burn tactics used to eliminate unwanted vegetation in preparation for making new farmland. The oak was also more tolerant for the decimation of the woods and the impoverishment of the soil. Moreover it was treated with circumspection because it produced strong timber as well as oak bark for tanning hides. ${ }^{56}$

Wood was a crucial and versatile material in pre-industrial times. ${ }^{57}$ The demand for wood was so great that 'wood thievery and wood vandalism' was considered a problem. It was one of the only concerns that a commission was able to voice about public morals in the North Brabant countryside in 1851. ${ }^{58}$ Poplar wood was used for clogs, oak for construction framing and furniture, pine for - among other things shoring in mineshafts, wood from grienden (swampy fields planted with willows) for woven materials, etc. Further differentiations were made. Thin willow branches from the grienden were used as wicker to make baskets, chairs and fences; thicker branches were used to make fascine mattresses for hydraulic constructions. Thick branches were also used for broom handles and the new shoots for barrel hoops. Firewood, a generic term for waste wood, unusable wood and dead wood suitable for burning, was in a class by itself. For some types of wood the domestic supply was adequate to the national demand, for example poplar and willow. Not only forests, but also wood banks and rows of trees along roads, fields and properties supplied the necessary material. Firewood partly satisfied the need for fuel, especially in the countryside but less so in the cities. The Netherlands was itself largely able to

\footnotetext{
${ }^{56}$ The oak also supplied acorns, a favourite food of pigs, that played a role in all the agricultural systems.

${ }^{57}$ See for the following: J. Radkau und I. Schäfer, Holz. Ein Naturstoff in der Technikgeschichte (Reinbek bei Hamburg 1987); J. Buis, Historia Forestis. Nederlandse bosgeschiedenis (Dissertation, Wageningen 1985); H. van Zon, Duurzame ontwikkeling in historisch perspectief. Enkele verkenningen (Nijmegen 2002), 55-85.

${ }^{58}$ See: Caspers, De hand van de mens..., 58. For the original text: A. Martini van Geffen, 'Zedelijke en materiële toestand der arbeidende bevolking ten platten lande. I. Nopens Noord-Braband', Verslag van het verhandelde op het vijfde Nederlandsche Landhuishoudkundig Congres, gehouden te Leiden van den 10den tot den 14den junij 1850 (Leiden 1850), Appendix no. 12, 104. The report is included in: J.L. Van Zanden, 'Den zedelijke en materiële toestand der arbeidende bevolking ten platten lande'. Een reeks rapporten uit 1851 (Historia Agriculturae XXI, Groningen 1991).
} 
compensate the shortage of fuel by extracting turf. The remainder was accounted for by the import of coal.

Timber for construction was another matter. In some regions it proved possible to re-use old timber or fell local trees, in particular, oaks. For the rest there was a centuries-old dependency on import. As early as the fourteenth century large quantities of wood were supplied via the Rhine. This Rhine trade peaked in the middle of the eighteenth century after which it rapidly declined. In the first half of the nineteenth century wood was imported above all from Norway and the Baltic Sea (Sweden, Finland, Estonia and the hinterlands of St. Petersburg): chiefly coniferous wood (pine and fir) and oak. The imported wood was used for constructing housing, public buildings, windmills, locks and bridges. Great quantities of logs were needed for pilings for among other things quays and buildings in peat soils. Shipbuilding was also a bulk consumer.

With the massive import of timber the Netherlands effectively relocated to foreign countries the problems it had with its own forests. The collapse of the Rhine timber trade was partly a consequence of the overexploitation of the forests along the upstream Rhine. Uncontrolled logging had transformed large parts of the Black Forest and other forested areas into lunar landscapes. ${ }^{59}$ The intensity of logging far outstripped the norm for natural recovery of the forest. Next to nothing was done about replanting. And it was not only the Netherlands that was consumed by wood hunger but also the German states. Great quantities of wood in the form of charcoal were burned there in blast furnaces in order to make iron.

\subsubsection{Prosperous Farming Landscape}

Since the onset of agriculture and the building of dikes every small corner of the Netherlands has repeatedly been torn down and built up again. ${ }^{60}$ On the sand grounds and in the coastal zones colonisation commenced far before the Christian era. In the peat bogs of the low Netherlands human intervention was delayed until around $1000 .{ }^{61}$ In that epoch the peat packets still towered several meters above sea level. Reclamation and turf extraction caused soil subsidence and changed the landscape into marshes, pools, lakes but above all polders and reclaimed lakes. Did this imply a reduction in biodiversity? According to the MSA indicator, $73 \%$ of the original

\footnotetext{
${ }^{59}$ The role of other factors like increased consumption in Prussia and rising prices is unclear. It is also uncertain how big a problem the deforestation was. Van Zon speaks of a catastrophic decimation of the German forests (Van Zon, Duurzame ontwikkeling, 85). Radkau and Schäfer are a bit more reticent: The deforestation was not so rigorous that recovery was impossible (Radkau and Schäfer, Holz, 139).

${ }^{60}$ See for a history of the Dutch landscapes among others: S. Barends, Het Nederlandse Landschap. Een historisch-geografische benadering (tenth revised edition, Utrecht 2010), 114-131.

${ }^{61}$ See for the history of the peat landscape among others: G.J. Borger, 'Agrarisch veenlandschap', in: S. Barends, Het Nederlandse Landschap. Een historisch-geografische benadering (tiende herziene druk, Utrecht 2010), 62-79 and websites like www.geologievannederland.nl
} 
species diversity still existed in 1850 . The question is whether this is an adequate picture of the actual biodiversity. Three objections may be raised.

First of all, the percentage seems a bit exaggerated for a country that had lost most of its original natural ecosystems. Here we are not counting the 'wastelands' (the heathlands) as original nature as per the MSA calculation. It may be the case that it was not so much the species diversity that declined but rather the population size of the individual species. Only a few species like the wolf, the brown bear, the elk and the beaver are known not to have survived the advent of humans with their penchant for hunting and transforming animal habitats. The high percentage then correctly expresses the modest decline in the original species diversity. Natural ecosystems were radically reduced in scope or nearly extinguished, but around 1850 small parts of the Netherlands still consisted of nearly authentic peat bogs, marsh forests and dunes. In some instances one could even speak of a large-scale natural landscape like the tidal flats of the Wadden Sea.

In the second place, the MSA provides not a single clue about the appearance of new species. The introduction and spread of agriculture must have facilitated the proliferation of entirely new species. Around 1850 the Netherlands harboured a large number of agricultural systems. The agricultural expert Staring, cited above, was able to identify fourteen of them in addition to special sectors like tobacco, flower bulbs and fruit orchards. There must have been a considerable variety of colonised ecosystems, each with their specific flora and fauna. The resultant biodiversity is difficult to reconstruct, but the variety of ecosystems each with their specific species diversity must have increased. In addition to the original ecosystems, new ones had emerged: the agrarian sand, clay, peat, dune and loess landscapes and their further differentiation into for example northern, southern and river clay landscapes. They contained biotopes that burgeoned with life, like the wood banks, the bluegrass lands, the brackish polders and the bramble hedges. In these cases human intervention did not eventuate in degradation of nature but rather in another 'nature' and presumably a more diverse one.

In the third place, the intensive exploitation of the available natural capital subjected the ecosystems and their constituent species to constant pressure. ${ }^{62}$ Ecosystems disappeared, like the primeval forests; they were threatened, like the heath meadows; or subject to irreversible processes, like the transformation of open water into fens. ${ }^{63}$ Overexploitation and exhaustion of the soil was an ever-present threat. 'Wild' animals were persistently pursued and killed for their fur, feathers or meat but also

\footnotetext{
${ }^{62}$ J.L. van Zanden en S.W. Verstegen, Groene geschiedenis van Nederland (Utrecht 1993), 17-31.

${ }^{63}$ In general the agrarian systems of the time facilitated stable ecosystems, an important precondition for continuity in species diversity. That also held for a large-scale practice like the extraction of clay with a production of an estimated $650 \mathrm{kton}$ in 1850, about $8 \%$ of the weight of all raw materials extracted from Dutch soil. This had a modest effect on the natural ecosystem. Extraction and processing into roof tiles and bricks took place in virtually every region where clay could be found. There was a concentration of factories in the floodplains of the rivers. Locally, extraction did disrupt the order of things. After a clay pit had been abandoned it frequently turned into a pond. At some sites along the river, thanks to sedimentation, these clay pits could be worked again after 50 years.
} 
Table 3.3 Total number of governmental bounties for killed 'harmfull animals' 1852-1857

\begin{tabular}{l|l}
\hline Type of animal & Numbers \\
\hline Weasels & 88,449 \\
\hline Polecats & 26,711 \\
\hline Sparrow Hawks & 16,626 \\
\hline Foxes & 5861 \\
\hline Kites & 5017 \\
\hline Goshawks & 2828 \\
\hline Falcons & 2787 \\
\hline Stoats & 2245 \\
\hline Buzzards & 1474 \\
\hline Beech Martens & 974 \\
\hline Martens & 675 \\
\hline Eagles & 219
\end{tabular}

Remark: Names used in the sources are retained here

Source: J.L van Zanden and S.W. Verstegen, Groene Geschiedenis van Nederland (Green History of the Netherlands) (Utrecht 1993), 27. Original source: J. Wttwaal, 'Over het verlenen van premiën voor het dooden van wezels en ander zoogenoemd schadelijk gedierte' (On the offering of bounties for the killing of weasels and other so-called harmful vermin') De Volksvlijt (1859), 317-345

because they threatened harvests and spoiled the hunt. Every province awarded bounties for the killing of polecats, sparrow hawks, foxes and other 'vermin.' (Table 3.3)

\subsection{A growing Economy, a Growing Population ${ }^{64}$}

The colonisation of nature had produced a rich variety of ecosystems. But did it also bring wealth to the Dutch? The colonised ecosystems were the original source of the three material flows identified in this book: biomass, fossil, and mineral. These provided the population with agricultural products, fossil resources (in particular turf) and building materials (among which sand and clay). These were processed, sold, consumed, used and exported. This enabled the import of yet other raw materials and products. What did this contribute to the development of welfare in terms of economic growth? We also look among the totality of material flows for

\footnotetext{
${ }^{64} \mathrm{An}$ analysis of economic development in the first half of the nineteenth century can be found in J.L van Zanden and A. Van Riel, Nederland 1780-1914. Staat, instituties en economische ontwikkeling (Amsterdam 2000), 149-208). The following section is based on this book.
} 
dominant industrial sectors. Which industrial sectors had the greatest impact on economic development? To find our way here we will first summarize economic developments prior to 1850 .

By the outset of the nineteenth century the Dutch economy already passed through a long and difficult period of adjustment. The Dutch Golden Age with its glory days of economic prosperity between 1580 and 1670 was followed by a long period of decline of international competitiveness, loss of market share, and stagnation. This economic malaise persisted through the collapse of the Republic of the Seven United Provinces in 1795 and hit bottom during the French annexation (1810-1813). International trade ground to a halt thanks to Napoleon's economic blockade of England. In the province of Holland and the other maritime regions manufacturing all but collapsed. The national debt, already sizable by the end of the eighteenth century, had swollen out of all proportion due to the virtually permanent state of war during the Batavian and French period (1795-1813). The founding of the Kingdom of the Netherlands in 1813 was followed by a period of uneven economic development. The two decades after 1820 comprised a period of structural growth in the Dutch economy, after which a new period of relative stagnation set in (see Table 3.4).

Initially, economic development after 1820 was shaped by conditions in the agricultural sector. Agriculture had to cope with the aftershocks of the Napoleonic period: steeply rising prices for agricultural produce immediately after the war followed by a dramatic decline. The price of wheat in Groningen, for example, declined from fl. 12.97 per hectoliter in 1817 to fl. 3.59 in 1823 . The price of rye also declined by more than $70 \%$. Prices for grain remained low in subsequent years. Prices for potatoes, dairy products and meat also declined, but less steeply. Farmers responded in various ways. For the dairy farmers in the provinces of Holland, Utrecht and Friesland these were favourable years and presumably better than the years after 1820. On the sea- clay soils in the coastal provinces farmers in part abandoned the tillage of wheat for that of potatoes and commercial crops like madder and flax. Meadowland was 'torn' and transformed into crop fields. Formerly mixed farms thus gradually assumed the character of specialized crop farms, a process that had been going on in the province of Zeeland for a time and that now gained momentum in the province of Groningen as well. Farmhands were fired to save on labour costs. Presumably the farmer, his family and other residents of the farm had to work harder. Potatoes and commercial crops required more intensive tillage (weeding, delving, sowing in rows, et cetera). On the sand grounds, mixed farms began to concentrate on growing potatoes, husbanding cattle and producing butter. That was accompanied by intensification of crop farming and long work days.

The 1820s witnessed growth across the board in manufacturing and services. The recovery of the domestic market after the Napoleonic period stimulated a strong 
Table 3.4 Growth in value added in the most important economic sectors, 1816-1850

\begin{tabular}{|c|c|c|c|}
\hline & \begin{tabular}{|l} 
Growth \\
$1816-1830$
\end{tabular} & \begin{tabular}{|l} 
Growth \\
$1830-1840$
\end{tabular} & \begin{tabular}{|l} 
Growth \\
$1840-1850$
\end{tabular} \\
\hline Agriculture & 0.6 & 1.4 & 1.2 \\
\hline Industry, among which & 2.7 & 2.4 & 0.5 \\
\hline Construction & 1.4 & 0.6 & -0.2 \\
\hline Clothing & 3.2 & -0.9 & 0.3 \\
\hline Textiles & 5.0 & 6.2 & -1.5 \\
\hline Foods & 4.1 & 2.8 & 0.5 \\
\hline Services, among which & 1.5 & 2.8 & 1.5 \\
\hline Internat. trade & 0.1 & 5.9 & 3.1 \\
\hline Domestic trade & 3.9 & 1.5 & 1.1 \\
\hline Maritime shipping & 4.5 & 9.8 & 2.4 \\
\hline River shipping & 1.0 & 5.8 & 0.7 \\
\hline Inland navigation & 0.6 & 2.5 & 0.9 \\
\hline Gross Domestic Product GDP & 1.6 & 2.3 & 1.1 \\
\hline Population & 1.2 & 0.9 & 0.7 \\
\hline GDP per capita & 0.4 & 1.4 & 0.8 \\
\hline $\begin{array}{l}\text { Labour productivity in } \\
\text { manufacturing }^{\mathrm{a}}\end{array}$ & $0.2(1807-1830)$ & $0.7(1830-1842)$ & $-0.6(1842-1860)$ \\
\hline
\end{tabular}

Remark: Value added and GDP in real prices

Source: J.L. van Zanden and A. van Riel, Nederland 1780-1914. Staat, instituties en economische ontwikkeling (The Netherlands 1780-1914. State, institutions and economic development) (n.p. 2000), Table 4.2, 153 and Table 6.3, 248. The figures for 1840-1850 differ between the tables. Here the data from Table 6.3 are used. The tables are based on: J.P. Smits, E. Horlings and J.L. van Zanden, Dutch GNP and its components, 1800-1913 (Groningen 2000)

aSource: J.P. Smits, 'The determinants of productivity growth in Dutch manufacturing, 1800 1913', European Review of Economic History, 4 (2000), pp. 223-246, graph 1

expansion of the food sector, the construction industry, the clothing industry and turf extraction. In this decennium the food sector, comprising more than $60 \%$ of industrial production, exhibited the highest rates of growth for the first half of the nineteenth century. Growth in the service sector was above all attributable to international trade and international transport. This was due on the one hand to increasing trade with the Dutch East Indies and on the other hand to trade with the eastern neighbour, Prussia. Textiles formed the bulk of goods transported to Java, while sugar, coffee and other colonial products comprised the return trade. Rhine barges transported colonial wares to the Prussian hinterland and cereals and coals back to the Netherlands. The Dutch Trading Company (Nederlandse Handelsmaatschappij, NHM) coordinated these flows of commerce. The interdependence of shipping and the grain trade became evident in the years around 1820 when grain prices fell sharply and Rhine shipping declined by about $60 \%$ and shipping to European harbours by $40 \%$.

Economic development in the 1830s was directly affected by the Belgian secession of 1830. Military expenditures demanded new and higher levels of 
taxation. In addition, there was a rise in prices of agricultural products and coal. This put an end to the rise of real income and the expansion of the domestic market. The building sector exhibited almost zero growth, while clothing production shrank and growth in the food sector was only modest. The sources of economic growth became narrower and were increasingly rooted in the so-called 'colonial complex.' The NHM reorganized the flows of commerce to and from the Dutch East Indies. They forcefully expanded the Dutch textile industry to compensate for the loss of Belgian production capacity. This required, among other things, mobilizing the countryside of the Twente region, where home weavers were put to work to produce huge quantities of textiles for Java. Maritime shipping also got a boost with the construction of great numbers of ships for the trade with Java. Sea trade and international commerce flourished.

All the agricultural sectors experienced a decisive upturn, particularly after 1835 . The farmers on the sea and river clay, in the peat and on the sand all profited from higher prices for agricultural produce (including dairy produce). Common lands on the sand grounds were reclaimed and their productivity increased by working more intensively and improving the quality of the cattle and the manure. The viability of smallholdings in certain regions like Twente improved thanks to NHM policy. Home-weaving formed a welcome supplement to farming income and spread the risk of insolvency.

The 1840s were marked by stagnation on three fronts: manufacturing, services and agriculture. Industrial development stagnated due to a crisis in the 'colonial complex.' Trade with Java declined precipitously and dragged textiles and shipping in the Netherlands along with it. At the same time the government's gradual dismantling of protectionist measures confronted the NHM with increasing international competition. The 'colonial complex' settled into a long-term malaise. Agriculture, by contrast, initially performed well. The liberalisation of international trade at the outset of the 1840s provoked a further increase in the prices of agricultural produce. Agricultural productivity increased along with the prices. 1845 was the turning point for the agricultural sector. Potato blight caused several years of failed or strongly reduced potato harvests, while in 1846 the rye harvest failed as well. The domestic market stagnated. Stagnation in one sector was not compensated by improved performance in other sectors. Moreover labour productivity declined and real wages and purchasing power trailed behind.

Three complexes in large part shaped economic development in the first half of the nineteenth century: (1) agriculture and foods, (2) building materials and construction, (3) the colonial complex (including textiles and shipbuilding). The first two complexes were part of the three big material flows generated by the natural capital of the Netherlands. These interacted with the domestic market. Growing demand stimulated the supply of food and buildings. Increasing supply allowed for a greater demand. Increasing demand expressed itself in particular in a growing population. Natural capital (and the colonial complex) enabled a remarkable population growth in the first half of the nineteenth century. 
Table 3.5 Growth of urban and rural population between 1795 and 1840

\begin{tabular}{l|l|l|l|l}
\hline & $\begin{array}{l}\text { Growth } \\
\text { population } \\
1795-1840(\%)\end{array}$ & $\begin{array}{l}\text { Growth rural } \\
\text { population } \\
1795-1840(\%)\end{array}$ & $\begin{array}{l}\text { Growth urban* } \\
\text { population } \\
1795-1840(\%)\end{array}$ & $\begin{array}{l}\text { Population } \\
1840(\mathrm{~N})\end{array}$ \\
\hline Drenthe & 83 & 81 & 86 & 72,484 \\
\hline Gelderland & 55 & 46 & 82 & 345,762 \\
\hline Groningen & 53 & 58 & 44 & 175,651 \\
\hline Utrecht & 49 & 47 & 56 & 145,132 \\
\hline Overijssel & 46 & 40 & 70 & 197,694 \\
\hline Noord-Brabant & 45 & 44 & 50 & 378,437 \\
\hline Limburg & 42 & 40 & 48 & 196,128 \\
\hline Friesland & 41 & 43 & 35 & 227,859 \\
\hline Zuid-Holland & 37 & 42 & 31 & 527,225 \\
\hline Zeeland & 32 & 43 & 9 & 151,358 \\
\hline Noord-Holland & 8 & 26 & 2 & 442,129 \\
\hline NETHERLANDS & 38 & 44 & 28 & $2,859,859$ \\
\hline
\end{tabular}

*Urban refers to places with more than 2500 inhabitants in 1840

Economic development, albeit of a vacillating nature, was accompanied by a vigorous growth of the Dutch population in the first half of the nineteenth century. While in the entire eighteenth century the population grew by only $7 \%$, in the 45 year period from 1795-1840 it increased by no less than 38\% (see Table 3.5). Population in the countryside grew significantly faster than that in the towns, namely $44 \%$ compared to $28 \%$. And the growth in the higher regions of the country was greater than in the low-lying portions. The agricultural system on the sand grounds appeared to have more than enough capacity to absorb population growth (in the province of Drenthe with a remarkable $81 \%$ ). Peat marshes, heathlands, grasslands and forests continued to be reclaimed. Smallholders increased productivity by working the land more intensively or opted for more profitable alternatives like dairy produce. They also wove textiles at home for the fabrikeur, under the puttingout system.

In terms of the gross domestic product per capita, the Dutch economy grew throughout the entire period 1816-1850. The 1830s were the most advantageous (annual growth of $\pm 1.4 \%$ ) and the 1840 s the least (annual growth of $\pm 0.8 \%$ ). That seems like a positive development. But what do these figures tell us about the quality of life of the population? This will be one of the topics of the next chapter. 


\section{Literature}

Alkemade, R., M. van Oorschot, L. Miles, C. Nellemann, M. Bakkenes and B. ten Brink (2009). 'GLOBIO3: A framework to investigate options for reducing global terrestrial biodiversity loss'. Ecosystems, 12, 374-390.

Alstorphius Grevelink, P.W. (1991). 'Zedelijke en materiële toestand der arbeidende bevolking ten platten lande. Nopens Drenthe (1850)'. In J.L. van Zanden, J.L. van (Ed.), 'Den zedelijke en materiële toestand der arbeidende bevolking ten platten lande'. Een reeks rapporten uit 1851. Groningen: Nederlands Agronomisch-Historisch Instituut. Original source: Verslag van het verhandelde op het vijfde Nederlandsche Landhuishoudkundig Congres, gehouden te Leiden van den 10den tot den 14den junij 1850 (1850), appendix no. 13, 109-118.

Bakker, M.S.C. (1992). 'Boter'. In H.W. Lintsen et al. (Ed.), Geschiedenis van de techniek in Nederland. De wording van een moderne samenleving 1800-1890 (pp. 103-133). Zutphen: Walburg Pers.

Barends, S. (2010). Het Nederlandse landschap: Een historisch-geografische benadering. Utrecht: Matrijs.

J.H. Beucker Andrea, J.H. (1991). 'Rapport ingediend voor het vijfde, Landhuishoudjundig Congres te Leyden, 11, 12, 13 junij 1850, betreffende een onderzoek naar den zedelijken en materiëlen toestand der arbeidende bevolking ten platten lande en van den middelen om dien zoveel mogelijk te verbeteren. [Friesland]'. In Zanden, J.L. van (red.), 'Den zedelijke en materiële toestand der arbeidende bevolking ten platten lande'. Een reeks rapporten uit 1851. Groningen: Nederlands Agronomisch-Historisch Instituut. Original source: Tijdschrift voor Staathuishoudkunde en Statistiek (1851), 6, 156-200.

Bieleman, J. (1987). Boeren op het Drentse zand 1600-1910: Een nieuwe visie op de 'oude'landbouw. Het Goy: Hes en de Graaf Publishers.

Bieleman, J. (2008). Boeren in Nederland: Geschiedenis van de landbouw 1500-2000. Amsterdam: Uitgeverij Boom.

Bosch, A., Ham W. van der, and Lintsen, H.W. (1998). Twee Eeuwen Rijkswaterstaat 1798-1998. Zaltbommel: Europese Bibliotheek.

Borger, G.J. (2010). 'Agrarisch veenlandschap'. In S. Barends, Het Nederlandse landschap: Een historisch-geografische benadering (pp. 62-79). Utrecht: Matrijs.

Brink, G. van den (1996). De grote overgang: Een lokaal onderzoek naar de modernisering van het bestaan Woensel 1670-1920. Nijmegen: SUN.

Caspers, T. (1992). De hand van de mens in het landschap. Haaren: Stichting het Noordbrabants Landschap.

Caspers, T. (1996). Natuur in Noord-Brabant: Twee eeuwen plant en dier. Haaren: Stichting het Noordbrabants Landschap.

Crijns, A.H. and F.W.J. Kriellaars (1987). Gemengd landbouwbedrijf op de zandgronden in NoordBrabant 1800-1885. Tilburg: Stichting Zuidelijk Historisch Contact.

Disco, C. and Lintsen, H.W. (2003). 'Het nijvere verbond'. In J. Schot, H.W. Lintsen, A. Rip and A.A. Albert de la Bruhèze (Ed.), Techniek in Nederland in de twintigste eeuw (Vol. I, pp. 55-63). Eindhoven: Stichting Historie der Techniek.

Goldewijk, K. (2011). 'The HYDE 3.1 spatially explicit database of human-induced global landuse change over the past 12,000 years'. Global Ecology and Biogeography, 20(1), 73-86.

Hacquebord, L (2010). 'Noorderlijk zeekleilandschap'. In S. Barends, Het Nederlandse landschap: Een historisch-geografische benadering (10 ${ }^{\text {th }}$ revised edition, pp. 16-31). Utrecht: Matrijs.

Hölsgens, H. N. M. (2016). Energy Transitions in the Netherlands: Sustainability Challenges in a Historical and Comparative Perspective. Groningen: University of Groningen, SOM research school.

Iterson, W. van (1868). Schets van de landhuishoudkunde der Meijerij. Groningen

Klerk, A.P. de (2010). 'Zuidwestelijk kleilandschap'. In S. Barends, Het Nederlandse landschap: Een historisch-geografische benadering (10 ${ }^{\text {th }}$ revised edition, pp. 32-45). Utrecht: Matrijs. 
Knippenberg, H. and Pater, B. de (1988). De eenwording van Nederland: Schaalvergroting en integratie sinds 1800 . Nijmegen: SUN.

Kooijmans, L. (2012). 'Holland op z'n wildst? De Vera-hypothese getoetst aan de prehistorie'. De Levende Natuur, 113(2), 62-66.

Lambert, F. (2016). Massastromen in Nederland. In de jaren 1850, 1913, 1970, 2010. Eindhoven: Eindhoven University of Technology (open-access research report)

Leenaers, H., Donkers, H. and Noordhoff Atlasproducties (2010). De bosatlas van Nederland waterland. Groningen: Noordhoff Uitgevers bv.

Leeuwen, W. van (1993). 'Een complexe sector'. In H.W. Lintsen et al. (Eds.), Geschiedenis van de techniek in Nederland. De wording van een moderne samenleving 1800-1890 (Vol. III, pp. 191-195).Zutphen: Walburg Pers.

Leeuwen W. van (1993). 'Waterbouw'. In H.W. Lintsen et al. (Eds.), Geschiedenis van de techniek in Nederland. De wording van een moderne samenleving 1800-1890 (Vol. III, pp. 233-249). Zutphen: Walburg Pers.

Leeuwen W. van (1993). 'Woning- en utiliteitsbouw'. In H.W. Lintsen et al. (Eds.), Geschiedenis van de techniek in Nederland. De wording van een moderne samenleving 1800-1890 (Vol. III, pp. 197-231). Zutphen: Walburg Pers.

Lintsen, H.W. (2005). Made in Holland: Een techniekgeschiedenis van Nederland [1800-2000]. Zutphen: Walburg Pers.

Moor, T. de (2015). The dilemma of the commoners: Understanding the use of common-pool resources in long-term perspective. Cambridge: Cambridge University Press.

Oudejans, A. (2012). Categorie een: Dierlijk afvalverwerking door de eeuwen heen. Mijnbestseller BV.

Renes, J. (1999). Landschappen van Maas en Peel. Maastricht: Eisma Edumedia.

Schot J.W. and Homburg E. (1993). 'Meekrap en garancine'. In Lintsen, H.W. et al. (Eds.), Geschiedenis van de techniek in Nederland. De wording van een moderne samenleving 1800 1890 (Vol. IV, pp. 222-239). Zutphen: Walburg Pers.

Stol, T. (2010). 'Turfwinningslandschap'. In S. Barends, Het Nederlandse landschap: Een historisch-geografische benadering. Utrecht: Matrijs.

Smits, J.P., E. Horlings and J.L. van Zanden (2000), Dutch GNP and its components, 1800-1913. Groningen: University of Groningen

Woud, A. van der (2010). Koninkrijk vol sloppen: Achterbuurten en vuil in de negentiende eeuw. Amsterdam: Bert Bakker.

Ven, G.P. van de (2003). Leefbaar laagland: Geschiedenis van de waterbeheersing en landaanwinning in Nederland. Utrecht: Matrijs.

Vloet, J.A.J. (2010). 'Zandlandschap'. In S. Barends, Het Nederlandse landschap: Een historischgeografische benadering $\left(10^{\text {th }}\right.$ revised edition, pp. 132-161). Utrecht: Matrijs.

Zanden, J.L. van (1985). De economische ontwikkeling van de Nederlandse landbouw in de negentiende eeuw, 1800-1914. Leiden: Koninklijke Brill NV.

Zanden, J.L. van (1991). 'Den zedelijke en materiële toestand der arbeidende bevolking ten platten lande'. Een reeks rapporten uit 1851. Groningen: Nederlands Agronomisch-Historisch Instituut.

Zanden, J.L. van and Verstegen, S.W. (1993). Groene geschiedenis van Nederland. Houten: Het Spectrum.

Zanden, J.L. van (1997). 'Werd de Gouden Eeuw uit turf geboren? Over het energieverbruik in de Republiek in de zeventiende en achttiende eeuw'. Tijdschrift voor geschiedenis, 110, 484-499.

Zanden, J.L., van en Riel, A. van (2000). Nederland 1780-1914. Staat, instituties en economische ontwikkeling. Amsterdam: Balans.

Zanden, J.L. van (2014). How was life? Global well-being since 1820. OECD. 
Zeehuisen, J. (1991). 'Statistieke bijdrage tot de kennis van den stoffelijken en zedelijken toestand van de landbouwende klasse in het kwartier Salland, provincie Overijssel'. In Zanden, J.L. van (red.), 'Den zedelijke en materiële toestand der arbeidende bevolking ten platten lande'. Een reeks rapporten uit 1851. Groningen: Nederlands Agronomisch-Historisch Instituut. Original source: Tijdschrift voor Staatshoudkunde en Statistiek (1851), 9, 375-408.

Zeeuw, J.W. de (1978). 'Peat and the Dutch Golden Age: The historical meaning of energy attainability'. A.A.G. Bijdragen 21: 3-31.

Zon, H. van (2002). Geschiedenis en duurzame ontwikkeling: Duurzame ontwikkelingen in historisch perspectief. Nijmegen: Netwerk Duurzaam Hoger Onderwijs.

Open Access This chapter is licensed under the terms of the Creative Commons Attribution 4.0 International License (http://creativecommons.org/licenses/by/4.0/), which permits use, sharing, adaptation, distribution and reproduction in any medium or format, as long as you give appropriate credit to the original author(s) and the source, provide a link to the Creative Commons license and indicate if changes were made.

The images or other third party material in this chapter are included in the chapter's Creative Commons license, unless indicated otherwise in a credit line to the material. If material is not included in the chapter's Creative Commons license and your intended use is not permitted by statutory regulation or exceeds the permitted use, you will need to obtain permission directly from the copyright holder. 